\title{
Review Article \\ Community based seed production through IRRI /IAAS projects in western mid hills of Nepal: A review
}

\author{
Bishnu Bilas Adhikari \\ Tribhuvan University, Institute of Agriculture and Animal Science (IAAS), \\ Rampur Campus, Khairahani, Chitwan, Nepal \\ Correspondence: bbadhikari@iaas.edu.np \\ ORCID: https://orcid.org/0000-0003-3860-1592 \\ Received: August 25, 2019; Accepted: November 18, 2019; Published: January 7, 2020 \\ (C) Copyright: Adhikari (2020).
}

\begin{abstract}
(c) (1) This work is licensed under a Creative Commons Attribution-Non Commercial 4.0 International License.
\end{abstract}

\begin{abstract}
A review on the community based seed production through IRRI/IAAS projects was made to know the seed production situation in western mid hills of Nepal. In Nepal, around $90 \%$ of seeds are supplied through informal sector where seed replacement rate (SRR) of major staple food crops is around $10 \%$. The formal seed supply systems are characterized by a vertically organized production and distribution of released or registered varieties by public and private organizations using agreed quality control mechanism. Community Based Seed Production (CBSP) is one of the most important community resources from which, small holder farmers can improve their livelihoods which serves as a means to attain food and nutrition security and income generation to the farmers. IRRI/IAAS collaborative projects (IFAD TAG 706, STRASA and CURE) have establish 15 CBSP organizations in Lamjung, Tanahun, Gorkha and Bajhang district since 2006 to 2014 and producing quality seed annually. Project team has developed a unique type of working modality to get success in research, development and technology dissemination. Conduction of PVS trial annually in key sites, regular training to farmers, exposure visit of farmers, monthly meeting with farmers, regular minikit distribution in new sites, award to best seed producers, collaborative work with respective DADOs are some examples. Though CBSPs have faced major challenges like limitation of fund for seed buying, availability of quality source seed in time and place, availability of machines like moisture meter, grading machines, weighing machines, seed storage problems, marketing problems, natural disasters etc. the projects have contributed in release of rice varieties like Ghaiya-2, Sukhadhan series from 1 to 6, Bahuguni, Hardinath-2 and Chiyarang sub-1 as drought tolerant, and Ramdhan, Sunaulo sugandha, Mithila, Swarna sub 1 and Barkhe 1022 as irrigated varieties during project period.
\end{abstract}

Keywords: Rouging, mother trial, revolving fund, quality seed, seed replacement rate

Correct citation: Adhikari B. B. (2020). Community based seed production through IRRI/IAAS projects in Western Midhills of Nepal: A Review. Journal of Agriculture and Natural Resources, 3(1), 320-332.DOI: https://doi.org/10.3126/janr.v3i1.27184 
Journal of Agriculture and Natural Resources (2020) 3(1): 320-332

ISSN: 2661-6270 (Print), ISSN: 2661-6289 (Online)

DOI: https://doi.org/10.3126/janr.v3i1.27184

\section{INTRODUCTION}

Rice (Oryza sativa L.) is a staple food crop of Nepal, which is cultivated from Terai $(60 \mathrm{~m})$ to mid hills and mountains (up to 3,050 m asl) with the dominance of small farmers (av. land holding $0.68 \mathrm{ha} / \mathrm{HH}$ ) where $45 \%$ of $\mathrm{HH}$ have below 0.5 ha (CBS, 2013). Rice crop can provides more than $20 \%$ of AGDP, $40 \%$ of calorie requirements and more than $25 \%$ of protein requirements of Nepalese diet from cereal crops (MoAC 2017). The productivity of rice in Nepal is $3.37 \mathrm{t} \mathrm{ha}^{-1}$, which is lower than that of neighboring countries like India (3.65 t $\left.\mathrm{ha}^{-1}\right)$, Bangladesh (4.37 $\left.\mathrm{t} \mathrm{ha}^{-1}\right)$, China $\left(6.72 \mathrm{t} \mathrm{ha}^{-1}\right)$, and the world average $\left(4.53 \mathrm{t} \mathrm{ha}^{-1}\right)$ (FAOSTAT 2014). There is a big yield gap between potential yield and national average yield of rice in Nepal.

Seed is the most fundamental and inexpensive input for increasing crop production. The availability of good quality seed in place, time and adequate quantity is considered to be one of the most significant pre-requisites to improve agricultural productivity in Nepal. The use of good quality seeds of high yielding varieties plays the most important role to increase crop production. Thompson (1979) reported that timely supply of sufficient quantity of quality seeds of high yielding varieties increases crop yields by $15-25 \%$. It is the fundamental input of food security, biodiversity conservation and vital agricultural input (Gautam, 2015). Sustainable increase in agriculture production requires continuous development of improved varieties of crops and regular supply of seeds to farmers (Joshi, 2015). However, Nepalese peoples have limited access to quality seeds of improved varieties in time and in place. The average seed replacement rate (SRR) of major staple food crops including rice is below 12\% as compared to desired level of $25 \%$ in Nepal which is remained unacceptably low (MoAD, 2013). The recommended SRR for self pollinated crops including rice is 25-30\% (Basnyat, 2010). In Nepal, around $90 \%$ of seeds are supplied through informal sector, which constitutes mainly seed exchange from farmer to farmer (through barter system), obtained from neighbor individual farmers or grain reserved from previous season's harvest (SQCC, 2013).

\section{CBSP Approach and its importance}

Community Based Seed Production (CBSP) is an approach to empower farmers for producing high yielding and locally preferred improved seed from source seed through community farmers. The major objective of CBSP is to provide quality seed to the farmers and other seed buyers, boost local seed markets, open avenues for people to start seed-trading business in the community (Engels et al., 2008). There are formal and informal seed supply systems are in practice in the community. The formal seed supply systems are characterized by a vertically organized production and distribution of released or registered varieties by public and private organizations using agreed quality control mechanism (Shrestha et al., 2013). The concept of CBSP is known in different ways around the world, which are farmer seed house, community gene bank, seed hut, seed center, seed savers group, seed producer group, seed library (Vernooy et al., 2015). CBSP programs are involved to produce foundation, certified and improved/truthful leveled seeds in a systematic process. The formal seeds supply systems in the past was not fixed and reliable in the community due to this reason farmers have high risk to get quality seed in the planting season. Because of such reason farmers may use either non - quality seed or the seeds imported through illicit measures. 
Journal of Agriculture and Natural Resources (2020) 3(1): 320-332

ISSN: 2661-6270 (Print), ISSN: 2661-6289 (Online)

DOI: https://doi.org/10.3126/janr.v3i1.27184

The informal seed system is characterized by farmers producing and preserving their own seeds for the next planting season. Farmers may exchange seeds with grains of other varieties (barter system) or exchange as gift. In this system, most of the indigenous and some improved varieties are produced and maintain in their own home (Shrestha et al., 2013).

In Nepal, the first CBSB was established in 1994 in Dalchoki, Lalitpur, with support of USC Canada-Nepal (Joshi, 2013; Bhandari et al., 2017) to handle orthodox crops eg cereals, grain legumes and vegetables. The government of Nepal started implementing community based seed banks in the fiscal year 2008/09 (Bhusal, 2018). CBSP is one of the most important community resources from which small holder farmers can improve their livelihoods. It is also serves as a means to attain food and nutrition security and income generation to the farmers. The CBSPs can be seen as examples of community level local institutions established to address issues of quality seed production from the activities of farmers' participatory varietal selection, seed production, processing, storage and marketing of quality seed (Joshi, 2013). These institutions are supported by a number of NGOs/INGOs and government agencies. The community level organizations have been maintaining their selected varieties based on their land type and farming system to get direct benefit from different commodities (Vernooy, 2013). Crop Development Directorate (CDD) under Department of Agriculture, Central and Regional Seed Labs, Seed Quality Control Centre (SQCC), National Seed Company (NSC), local NGOs and INGOs like IRRI/IAAS projects (CURE/STRASA) etc are directly involved in local level seed production after the establishment of seed institutions.

In Nepal, there are a total of 46 registered and operational CBSPs in the national system of which 40 are well functioning and most of them are working on orthodox crops (Joshi, 2018). The higher volume seed production of selected improved as well as local varieties that have high demand in the locality is the main task performed by CBSP in their community. This function of CBSP has been highly valued by local people because they can buy the quality seeds of different varieties at a reasonable price on time and in place. The trained local farmers are involved for production, processing, collection, storage and distribution of quality seed in their community, which helps to reduce the import flow of exotic seeds, increase seed replacement rate (SRR) in the locality. The major functions of CBSP are to preserve seeds of local varieties for use, providing easy access to seed and planting materials in the community and to promote farmers' rights and food sovereignty (Vernooy et al., 2014). Thus, it is a mixed model, focusing on the circulation of improved varieties to enhance their availability which in return will improve food security and also conserve the endangered landraces in the community. CBSB can enhance the resilience of local farmers in the context of climate change (Vernooy et al., 2017). Community seed banks are also important for sharing knowledge and experiences among farmers (Shrestha et al., 2012).

\section{CBSP works through IRRI/IAAS projects}

The first CBSP institution Sundar seed producer group was established in 2006 at Sundarbazar Lamjung by IRRI led IFAD funded project "Managing Rice Landscapes in Marginal Upland for Household Food Security and Environmental Sustainability" (IFAD TAG706). This project was implemented by a research team of IAAS in two districts Lamjung and Tanahun since 2005 to 2008. Participatory Varietal Selection (PVS) trials like 
Journal of Agriculture and Natural Resources (2020) 3(1): 320-332

ISSN: 2661-6270 (Print), ISSN: 2661-6289 (Online)

DOI: https://doi.org/10.3126/janr.v3i1.27184

mother trial, baby trial, farmers' acceptance test etc. were conducted on upland as well as rainfed lowland rice at Sundarbazar as key site. Farmers were involved in selection process at maturity stage of the tested genotypes. The best selected genotypes in the experiment were requested to grow for the next year and demanded the seed. The research team realized a need of establishment of seed producer group to supply the seed of best genotype as their demand. A seven member Sundar seed producer group was established in Paundi bazaar in 2006 which was the first seed producer group of Lamjung district. Later on, it was upscaled to Sundar seed Cooperative Ltd. in 2008. As project objective, the verified technologies were disseminated to neighboring district Tanahun in 2007. The Pragati seed producing group (SPG), the $1^{\text {st }}$ SPG of Tanahun district was established at Purkot, Tanahun in 2008 (Table 1). After termination of IFAD-TAG 706 project, Consortium for Unfavorable Rice Environment (CURE) project funded by International Fund for Agriculture Development (IFAD) was initiated in 2010. The Bhrikuti SPG was established in Palungtar VDC of Gorkha as the $1^{\text {st }}$ SPG of Gorkha district in 2010. During CURE project period (2010-2014), a total of 13 SPGs and two Cooperatives were established in Lamjung, Tanahun, Gorkha and Bajhang districts under Technical Innovation Services (TIS) in different years. These community seed groups draw much attention as they are used as platform to strengthen the farmer seed systems, to strengthen the seed sector, raise the SRR for increasing production and productivity of major food crops and increasing food security in the hills of Nepal. These community based seed producer groups became very prominent in different communities.

Table 1. Community based seed producer organizations established in western mid hill districts of Nepal under IAAS/IRRI projects

\begin{tabular}{cllcccc}
\hline SN & $\begin{array}{l}\text { Seed Company/Seed } \\
\text { Producing Group (SPG) }\end{array}$ & Village / District & $\begin{array}{l}\text { Estd. } \\
\text { Year }\end{array}$ & $\begin{array}{l}\text { Total } \\
\text { member }\end{array}$ & $\begin{array}{l}\text { Women } \\
\text { members } \\
(\%)\end{array}$ & $\begin{array}{l}\text { Registered } \\
\text { Year }\end{array}$ \\
\hline 1 & Sundar Seed Co. Ltd. & Sundarbazar, Lamjung & 2007 & 40 & 18 & 2009 \\
2 & Pragati SPG & Purkot, Tanahun & 2008 & 60 & 40 & 2009 \\
3 & Tarku SPG & Tarku, Lamjung & 2009 & 36 & 22 & 2012 \\
4 & Jaya Buddha SPG & Bhanu, Tanahun & 2009 & 38 & 32 & 2010 \\
5 & Hariyali Ag. Co. Ltd. & Purkot, Tanahun & 2010 & 25 & 48 & 2010 \\
6 & Majhuwa women SPG & Sundarbazar, Lamjung & 2010 & 21 & 100 & 2011 \\
7 & Harrabot women SPG & Harrabot, Lamjung & 2010 & 34 & 100 & 2011 \\
8 & Bhrikuti SPG & Palungtar, Gorkha & 2010 & 28 & 21 & 2011 \\
9 & Gaikhur SPG & Gaikhur, Gorkha & 2010 & 46 & 48 & 2012 \\
10 & Rayel SPG & Rayel, Bajhang & 2011 & 15 & 40 & 2012 \\
11 & Parakatane SPG & Parakatane, Bajhang & 2011 & 15 & 34 & 2012 \\
12 & Bhairabnath SPG & Bhairabnath, Bajhang & 2011 & 15 & 34 & 2012 \\
13 & Saghan Bali SPG & Archalbot, Lamjung & 2012 & 25 & 60 & 2012 \\
14 & Pauwatar SPG & Gaikhur, Gorkha & 2012 & 22 & 50 & 2012 \\
15 & Ramgha Suryapal SPG & Ramgha, Lamjung & 2014 & 22 & 42 & 2012 \\
\hline & & & \multicolumn{2}{c}{ Source: Project annual reports (2006-2014) }
\end{tabular}

\section{CBSP Modality applied by projects}

In Nepal, CSBs are supported by a community led seed management approach that includes production, collection, processing, storage, distribution and marketing of local as well as improved varieties. CBSP programs can be used as a platform for community institutions to strengthen the roles of the farmer seed systems. CBSPs are usually inexpensive, employing 
Journal of Agriculture and Natural Resources (2020) 3(1): 320-332

ISSN: 2661-6270 (Print), ISSN: 2661-6289 (Online)

DOI: https://doi.org/10.3126/janr.v3i1.27184

relatively simple low cost storage and documentation technologies. For the quality seed production, the following processes were conducted by CBSPs under IRRI/IAAS led projects.

\section{Seed group formation and registration}

Based on the interest and demand of the community people within project area, a farmers' meeting was organized and formed an executive seed producer committee. The member in the committee was 7 to 11 based on interested and curiosity of farmers. The SPG was registered in concerned DADOs.

\section{Regular saving}

Regular monthly saving was done by the farmers to raise the fund which was used as revolving fund for seed purchasing. Minimum 20 to 100 rupees per month from each member was collected, that fund became very useful for buying of inputs like seed, fertilizer, pesticide etc.

\section{Conduction of Participatory Variety Selection (PVS) trials}

PVS trials on upland rice and rainfed lowland rice was conducted every year in the key sites (Sundarbazar village for lowland rice (paddy) and Purkot village for upland rice) for selection of new genotypes for developing new variety in the future.

\section{Varietal demonstration}

The selected genotypes from the PVS trials were demonstrated in each village every year for extension and dissemination of new verified technology to new sites.

\section{Variety release}

The multilocation trials data were submitted to National Rice Research Program (NRRP) to release best selected genotypes. IRRI/IAAS Projects have direct contribution to release Ghaiya-2, Ramdhan, Sunaulo sugandha, Mithila, Sukhadhan-1, Sukhadhan-2, Sukhadhan-3, Sukhadhan-4, Sukhadhan-5, Sukhadhan-6, Bahuguni, Chiyarang sub-1, Hardinath-2 etc.

\section{Seed multiplication program}

The seed multiplication programs were started after validation of new genotypes in different villages in their own risk. The systematic seed multiplication program was conducted through SPGs for formally released varieties.

\section{Arrangement of foundation seed}

The demand of foundation seed of each SPG and Cooperative for the coming season was given one year before through concerned DADOs. DADOs helped to include the demand of seed in the balance sheet of Seed Quality Control Centre. The concerned CBSPs are collected their demanded source seed next year from the nearest station. DADOs have supported 50\% subsidy and total seed transportation fare to the SPGs and cooperatives.

\section{Training and exposure visit}

Regular farmers' trainings were organized by IRRI projects on seed production, seed quality control, and seed processing and marketing in each village annually. First preparatory 
Journal of Agriculture and Natural Resources (2020) 3(1): 320-332

ISSN: 2661-6270 (Print), ISSN: 2661-6289 (Online)

DOI: https://doi.org/10.3126/janr.v3i1.27184

training was organized before planting (May-June) and second training just before harvesting of crop (Oct-Nov). The main objective of first training was to teach about nursery bed management, transplanting and intercultural operations while second training for seed processing, marketing and storage of rice seed.

Regular farmers' exposure visit was organized by the project for seed producer farmers annually. They visited in different seed producer groups and seed companies of different districts, National Seed Company (NSC), National Research Centers, Government farms, universities commercial farms etc for their exposure.

\section{Seed quality control}

Quality control committee (QCC) was formed each year in each SPG and cooperative for maintaining quality assurance. QCC visited seed producer farmers' seed plot about three times i.e., during $2^{\text {nd }}$ weeding, panicle emergence and at maturity. DADO representative, project representative, seed inspector from Regional Seed Testing lab, Bhairahawa were also involved timely in the team to monitor the standing crop for seed quality control and certification. Due to lack of sufficient manpower and system complexity of regional seed laboratory who is responsible for seed certification, all the CBSPs could not certified their seed effectively each year and most them are producing "truthful labeled seed" or "quality declared seed".

\section{Seed processing and storage}

Seed storage houses are constructed in different villages for processing and storage of seed. Nepal-Irrigation and water resource management (IWRMP), Crop Development Directorate under DOA, DFID had supported to construct the seed storage building in different villages. About 50 t capacity buildings are constructed in six villages: Sundarbazar, Purkot, Palungtar, Chardi, Harrabot and Archalbot. The seed is collected by those SPGs and Cooperatives who have storage facility and those groups who have not such facilities, they sell their product to those who have storage building.

\section{Price determination and seed collection}

Seeds are collected by the SPG committee from its seed members. Seed prices determination is done with the involvement of concerned DADOs, project representatives, members from different seed groups, cooperatives and agrovets before purchasing of seed at first (purchasing rate) and after proper processing, tagging, bagging, and storage for about 5 months. The $2^{\text {nd }}$ price determination is done before selling of seed (for selling rate). Price is determined based on current price of grains of respective varieties, price reference of SPGs and Cooperatives of Chitwan district (whose seed price is directly influenced the local market competition), selling price rate of previous year, grain types (fine and coarse type), storage cost, staff salary, room rent, profit margin etc.

\section{Seed marketing}

The final product is marketed primarily to the farmers in the same district and neighboring districts. Some seed is brought by different local institutions like DADOs, local NGOs/INGOs, seed companies etc. 
Journal of Agriculture and Natural Resources (2020) 3(1): 320-332

ISSN: 2661-6270 (Print), ISSN: 2661-6289 (Online)

DOI: https://doi.org/10.3126/janr.v3i1.27184

\section{Beneficiaries of CBSP program}

Paudel (2014) reported that Sundar Seed Cooperative has contributed about $11.85 \%$ of the total rice seed requirement of the Lamjung district, where the seed replacement rate was $53.33 \%$ in Sundarbazar village during 2013. The $2^{\text {nd }}$ short survey conducted by the project research team during 2018 at Sundarbazar, Harrabot and Archalbot villages of Lamjung district and found that about $26 \%$ of the total need of Lamjung is supplied from these three SPGs where the SRR was $58.36 \%$.

President of Sundar Seed Cooperative, Mr. Chandra Prasad Pokhrel said that before establishment of Sundar SPG (in 2006) there were very less number of improved rice varieties used by the farmers at Sundarbazar. The popular varieties were Gokule Mansuli, Eakle (aromatic), Dalle, Makwanpur-1, Anadi (glutinous var.), Jhinuwa (aromatic) etc. The coverage of Gokule mansuli was about $75 \%$ where the neck blast problem was maximum and the productivity was about $4 \mathrm{t} \mathrm{ha}^{-1}$. After introducing drought tolerant and non-drought tolerant varieties from IRRI projects, about $98 \%$ of rice area is covered by improved varieties like Sukhadhan-1, Sukhadhan-2, Sukhadhan-3, Sukhadhan-4, Sukhadhan-6, DRR-44, Chiyarang sub-1, Hardinath-1, Hardinath-3 (for rainfed condition) and Sunaulo sugandha, Ramdhan, Loktantra, Sabitri (for irrigated condition). He said, after the dissemination of new varieties through Sundar cooperative, about $75-80 \%$ of rice yield is increased. In drought prone areas, after the use of Droght Tolerant Rice Varieties (DTRVs), about $100 \%$ yield is increased. He said that Sukhadhan-2 variety is the "Gift of god" to the farmers, which can be grown in rainfed lowland as well as in upland condition as Ghaiya (upland rice).

\section{Role of CBSP program}

- Established Community Based Seed Production (CPSB) program can produce and sale the quality seed at right place, at right time and in affordable price (Pokhrel et al., 2012).

- CBSP can maintain the seeds of modern and local varieties at the community level.

- They guarantee seed sovereignity and seed multiplication, including PVS trials (Shrestha et al., 2013).

- CBSP program can increase income through the sales of seeds with low production cost.

- CBSP program can share commercial seed production, processing, storage and marketing knowledge to other farmers (Vernooy et al., 2014).

- CBSP helps to increase the productivity of rice as well as non-rice crops (Thompson, 1979).

- It creates changes that will improve the standard of living of the rural people, reducing poverty and improve food security (Joshi, 2013).

- Provides a platform for social learning and other collective actions and develop linkage and collaboration with local government and line agencies too (Shrestha et al., 2013).

- CBSPs help to organize farmers and see a community seed bank as a good way to support the empowerment process (Gautam, 2015).

\section{Keys for CBSP success}

Under IRRI/IAAS projects, the seed production programs are getting success day by day that might be due to presence of experienced personal in executive committee in each CBSP. The retired agricultural officers, extension officers and retired teachers have been involved as president in the committee. Their long experience, skill and knowledge are useful in seed 
Journal of Agriculture and Natural Resources (2020) 3(1): 320-332

ISSN: 2661-6270 (Print), ISSN: 2661-6289 (Online)

DOI: https://doi.org/10.3126/janr.v3i1.27184

production. The seed programs were lunched under District Seed Self Sufficiency Program of Nepal government which was launched in project districts too (Shrestha et al., 2013). So that farmers were able to get few supports like training, visit, seed subsidy, seed plot monitoring, seed marketing from concerned DADOs and Crop Development Directorate (CDD). They were got regular technical as well as material support from IRRI projects. Local CSBs are joined with national seed networks such as seed enterprises, seed companies, seed processing units, seed testing laboratory, seed quality control center, seed marketing channels etc (Joshi, 2013) which will make easy to conduct seed activities in sustainable basis. Local government has provided land for mist of CBSPs for construction of storage building and threshing floor. Every CBSP has raised small fund in the villages every month. This fund plays a key role for launching different seed activities in the villages.

The CBSP's have a clear organizational structure and the members have defined roles and responsibilities. We assumed this has helped in the development of human capital and the empowerment of the members of the groups. Ladies participation in each CBSP increasing day by day. It adds to the capability of the community to produce quality seed and manage properly. A key factor in the success of the seed groups and cooperative lies on the ability of their members to organize themselves based on a clear structure, and perform their roles defined in the group. This has also encouraged an increase in the participation of women in each seed group. It adds to the capability of the community to produce quality seeds, and manage them properly.

\section{Sustainability of CBSP program}

A strong sense of community ownership and belonging is important factor of viability. Regular exchanges of seeds, knowledge and skill are the beating heart of CBSPs. Once each CBSP is linked up with the market with their quality labeled seeds. In the case of seed production, CBOs are provided a seed balance sheet prepared by the Seed Quality Control Centre (SQCC) so that they can enter into the seed demand supply channel. The SQCC (2013) reported that formal linkages must be taken between CBSPs and the national genebank, regional and international genebanks and the formal seed system for their sustainability. Some SPGs have received grants from national NGOs, VDC, CDC and DDC to strengthen their technical, financial and management capacity. For example, Sundar Seed Ltd. Lamjung received $1 / 4^{\text {th }}$ ha of land for building construction from local government and prepared a storage building. Similarly, Bhrikuti SPG of Palungtar, Gorkha has prepared two buildings with the budget of about NRs. 30, 00000 (equivalent to 30,000 US\$) from Irrigation and Water Resource Management Project (IWRMP) in 2015. SPGs like Harrabot, Pragati, Ramgha Suryapal, and Sundar Seed Coop Ltd. have got support to built one storage building having $50 \mathrm{t}$ capacity from DFID UK. Now a total of 6 CBOs have good storage facility. From theses evidences, it seems that local CBOs are sustainable in the future. Bhusal et al., (2018) reported that the monitoring and evaluation of CBSPs should be linked to the operations of the local government and other non-government institutions working in the local level. Strong social networks, an effective institutional mechanism, dedicated leadership, social inclusion and a strategic long-term work plan are other key factors that contribute to sustainability. 
Journal of Agriculture and Natural Resources (2020) 3(1): 320-332

ISSN: 2661-6270 (Print), ISSN: 2661-6289 (Online)

DOI: https://doi.org/10.3126/janr.v3i1.27184

\section{Governance of CBSP program}

A CBSP by terminology itself is a community-managed approach that expands local knowledge and skills from the household to the community level through collective actions and motivations. The value of the CBSP is that the system is governed under the leadership of local people and ruled by locally developed rules and regulations. It facilitates to build social assets through mobilization of the local community, leading to community empowerment, and creates a platform of community based management practices. The success and sustainability of CBSP s depend upon how technical knowledge and management capacity of local Champions are enhanced and how local institutions are empowered to make self-directed decision making. Such agents play a key role in establishing a legitimate governing structure and mechanism for seed production, distribution, sharing seeds and benefits to the community.

\section{Role of local champions for success of CBSP program}

Farmers' seed systems can be substantially improved through the introduction of scientific knowledge and practices developed by the formal seed system. There is renewed interest in the theory and practices of CBSP for strengthening farmers' seed and food security. At the outset, it is critical that one fully experienced community organizer should be based in the community as a Champion to present new ideas and techniques to adequately address community problems and break down barriers. Experience of social mobilization and technical competencies of such a community organizer is a key external factor for the success of the CBSP in Lamjung and in other communities. Such community Drivers should work locally for developing teams of local leaders internally to mobilize social capital and bring about behavioural change. Exposure visits of seed producer farmers groups to successful community, seed companies, research farms and national development farm play vital role to Champions.

\section{Challenges of CBSP program}

Despite several positive aspects of CBSPs have faced a number of technical and policy related challenges. The guidelines do not say anything about existing CBSPs. At the local level, there has been good collaboration with VDC, DDC and DADO, but this is mostly on an ad-hoc basis and it is largely dependent on personal relationships. CBSPs are struggling to obtain institutional support from local governments.

\section{Financial problem}

Due to lack of sufficient fund of local CBSPs, they could not buy the whole produced seed from the seed producer farmers each year. In few years, the huge amount of left over seed (about half of the total produced) was kept by the seed producer farmers which were used for consumption. The bank or finance companies were not provided the loan to the CBSPs without deposit of their land ownership certificate. Most of the CBSPs do not have their land ownership certificate and the individual farmers (members) are hesitated to provide his/her certificate to the CBSPs for getting loan. The support from the government as well as I/NGOs is very nominal. The lack of public support for CBSPs is considered one of the key issues affecting the progress of CBSPs (Khanal and Maharjan, 2015). 
Journal of Agriculture and Natural Resources (2020) 3(1): 320-332

ISSN: 2661-6270 (Print), ISSN: 2661-6289 (Online)

DOI: https://doi.org/10.3126/janr.v3i1.27184

\section{Poor seed marketing network}

The seed marketing and market information system is not yet well organized in the overall seed system in Nepal (Timsina and Shivakoti, 2018). It is found that farmers are not aware about seed system and have limited access to seed related information even when sufficient quantities of seed are available in the local community. This situation may be due to lack of strong social networks among farmers (Siart, 2008), Due to lack of strong marketing net work the collected seed by CBSPs could not sell in time. The uncertainty of climate (long drought, flood), infestation of insect, pest and diseases, poor economic status of farmers, fragmentation of land, illiterate farmers, competitive market (competition with hybrid seed from India and inbred certified seed from CBSP s of Chitwan district) are some important challenges of CBSPs of mid hills of Nepal.

\section{Managerial problems}

In the CBSP's executive committee consists of farmer of old age rather than young and youth with less knowledge of accounting. Most of the literate young are in abroad for their employment. The involvement old farmers in commercial seed production faced different problem in management. Bhusal (2018) reported that strong leadership is one of the most important factors for running a sound CBSP. Low level of knowledge and capacity at the farm level, low quality seed production, and low seed storage and processing facilities are also the major constraints (UMN, 2015).

\section{Technical problems}

To get quality seed assurance, there is less provision of quality seed control machineries in CBOs. Proper maintaining isolation distance, timely rouging, seed cleaning, drying, grading, proper storage are some examples of technical problems. Unavailability of source seed (foundation seed) in time and place as farmers demand is another problem. Similarly, timely availability of fertilizers, insecticides and pesticides are also some problems.

\section{Unsustainable seed groups}

Those CBSPs who have less fixed property, less trained man power, less linkage with line agencies (GOs, NGOs and INGOs), less amount revolving fund have higher chances of failure. There are some SPGs who have less fund, lack of good storage facility, lack of dynamic leadership, lack of manpower, inadequate market linkages could not be sustained after completion of projects. Pauwatar, Tarku, Gaikhur SPGs are some examples.

\section{CONCLUSION}

Majority of the Nepalese farmers fulfilled their seed demand through informal sources and are using low quality seed. From the small and dynamic collaborative work with between IAAS and respected DADOs of different districts in western mid hill districts through different IRRI projects became very popular in the farming communities. The validated and upscaled new technologies dissemination to the farmers became very popular among farmers in upland and rainfed lowland conditions. The development of knowledge, skills and experiences in technology validation, transformation and adoption become useful to increase the production and productivity of rice crop. The integration of the technology validation, upscaling, seed production, seed marketing became an effective and sustainable model to the farming communities in the mid hills of Nepal. There are some problems related to pricing, 
Journal of Agriculture and Natural Resources (2020) 3(1): 320-332

ISSN: 2661-6270 (Print), ISSN: 2661-6289 (Online)

DOI: https://doi.org/10.3126/janr.v3i1.27184

marketing, infrastructure, varietal development, planning policies, rules and regulations. To get more success, there is a strong need of developing a long term seed strategy, vision and plan by the government and should develop strong linkage between research, extension, education and private sectors on seed production.

\section{LESSON LEARNED}

- Awareness of local farmers has been central point to establish CBSP in any villages.

- The establishment of saving fund and its mobilization for income generation is an important strategy to sustain the CBSP.

- Large volume of seed could not buy in time due to lack of revolving fund of some CSBs in different years and leftover seed was used as grain for consumption.

- Establishment of seed network with national level is very important, which helps to establish relationship between CBSPs and seed line agencies (SQCC, CDD, National seed companies, NARC stations etc).

- Encouragement to women farmers to participate in the research and development activities is very important.

- The technical manpower in the Regional Seed Testing Laboratory (RSTL) should be increased to provide effective services for seed groups and cooperatives.

- Seed processing machines including seed sewing machines, moisture meter, graders, and other necessary support should be given in package with output based single funnel support system.

- Regular training and exposure visit is necessary for newly established CBSP groups and coops in different districts.

- At least $50 \%$ seed farmers should be trained on quality seed production, processing, post harvest management and marketing of seed.

- Need to arrange soft loan facility, insurance, customs subsidy, financial support etc to make rice seed business sustainable.

\section{ACKNOWLEDGEMENT}

Author is grateful to different projects like IFAD TAG 706, STRASA, CURE, EC-IFAD under International Rice Research Institute (IRRI) for the arrangement of fund to conduct research and development activities in mid hill districts in Nepal.

\section{AUTHORS CONTRIBUTION}

As Project Coordinator in different project under IRRI, author involved conduction of research and development activities and writing of this manuscript.

\section{Conflict of Interest}

The author declares no conflicts of interest regarding publication of this manuscript. 
Journal of Agriculture and Natural Resources (2020) 3(1): 320-332

ISSN: 2661-6270 (Print), ISSN: 2661-6289 (Online)

DOI: https://doi.org/10.3126/janr.v3i1.27184

\section{REFERENCES}

Basnyat, B. (2010). Improving seed security through the expansion of seed multiplication farms in the public, private and cooperative sectors in Nepal. Economic Policy Network II, MOF/ADB, Kathmandu, Nepal.

Bhandari, B., Joshi, B. K., Shrestha, P., Sthapit, S., Chaudhary, P., \& Acharya, A. K. (2017). Custodian farmers, agrobiodiversity rich areas and agrobiodiversity conservation initiatives at grass root levels in Nepal. In: Conservation and Utilization of Agricultural Plant Genetic Resources in Nepal (BK Joshi, HB KC and AK Acharya, eds). Proceedings of 2nd National Workshop, 22-23 May 2017, Dhulikhel; NAGRC, FDD, DoA and MoAD; Kathmandu, Nepal; pp.92-101.

Bhusal, M., Acharya, P., \& Thapa Chhetri, B. (2018). Government Implemented Community Seed Banks: Approach and Progress. In: Comminity Seed Banks in Nepal (Joshi B. K., Shrestha P, Gauchan D and Vernooy R, eds.). $2^{\text {nd }}$ national workshop proceedings 3-5 may 2018, Kathmandu.

CBS. (2011). National sample census of agriculture Nepal, 2011: Highlights. National Planning Commission Secretariat, Central Bureau of Statistics, Thapathali, Kathmandu, Nepal

Engels, J.M.M., Polreich, S., \& Dulloo, M. E. (2008). Role of community genebanks in conservation and use of crop genetic resources in Ethiopia. In M.H. Thijssen, Z. Bishaw, A. Beshir and W.S. de Boef (eds.) Farmers' seeds and varieties, supporting informal seed supply in Ethiopia.Washingten International, Wageningen, pp. 149-159.

FAOSTAT (2012). Crop information 2011. Available via http://faostat.fao.org/site/567/DesktopDefault.aspx Page ID=567\#ancor. Accessed 2 February 2018.

FAOSTAT. (2014). Crop information 2014. Available via http://faostat.fao.org/site/567/DesktopDefault.aspx?PageID=567\#ancor. Accessed 27 July 2019.

Gauchan, D. (2015). Research and Support Services in Seed Production and Supply in Nepal. Thematic paper presented at the Seed Summit, 2015, Seed Quality Control Centre, Kathmandu, Nepal.

Joshi, B. K. (2013). A brief overview of community seed bank initiatives in Nepal. In: Community Seed Banks in Nepal: Past, Present, Future (P Shrestha, R Vernooy and P Chaudhary, eds). Proceedings of a National Workshop, LI-BIRD/USC Canada Asia/Oxfam/The Development Fund/IFAD/Bioversity International, 14-15 June 2012, Pokhara, Nepal; pp.41-46.

Joshi, B. K., Ghimire, K. H., \& Sahi, D. (2018). The national genebank's promotion of seed Banks: Stats and Strategy. In: Comminity Seed Banks in Nepal (Joshi B. K., Shrestha P, Gauchan D and Vernooy R, eds.). $2^{\text {nd }}$ national workshop proceedings 3-5 may 2018, Kathmandu.

Joshi, G. R. (2015). Seed Enterprise Development in Nepal: Opportunities and Challenges. Thematic paper presented at the Seed Summit, 2015, Seed Quality Control Centre, Kathmandu, Nepal.

Khanal, N.P. \& Maharjan, K. L. (2015). Community seed production sustainability in ricewheat farming. Springer. ISBN 978-4-431-55473-8, pp. 35-54 
Journal of Agriculture and Natural Resources (2020) 3(1): 320-332

ISSN: 2661-6270 (Print), ISSN: 2661-6289 (Online)

DOI: https://doi.org/10.3126/janr.v3i1.27184

MoAC. (2017). Statistical Information on Nepalese Agriculture. Ministry of Agriculture and Cooperatives, Singha Durbar, Annual Report, Nepal.

MoAD. (2013). National Seed vision 2025, Seed Act (1988) amended in 2008 and Seed Regulation (2013). National Seed Board (NSB), Ministry of Agriculture Development (MoAD), Kathmandu, Nepal. 21p.

https://www.researchgate.net/publication/308417123_Rice_seed_production_and_marketing _practices_in_Nepal [accessed May 31 2019].

Paudel, M. R., Adhikari, B. B., Dhakal, C. K., \& Shrestha, K. (2014). Role of Sundar Seed Cooperative for rice (Oryza sativa L.) seed supply in Lamjung: A case study at Sundarbazar Lamjung. Proceedings. IAAS Lamjung Campus, Lamjung, Nepal.

Shrestha, P., Sthapit, S., Devkota, R., \& Vernooy, R. (2012). National workshop on community seed banks: Workshop summary report. 14-15/06/2012, Pokhara. LIBIRD/USC Canada Asia/Oxfam Nepal/Bioversity International.

Shrestha, P., Vernooy, R., \& Chaudhary, P. (2013). Community Seed Banks in Nepal: Past, Present and Future. Proceedings of a National Workshop. LI-BIRD/USG Canada Asia/Oxfarm/The Development Fund/IFAD/Biodiversity International, 14-15 June 2012. Pokhara, Nepal.

Shrestha, P., Gezu, G., Swain, S., Lassaigne, B., Subedi, A., \& De Boef. W. (2013). The community seed bank: a common driver for community biodiversity management: promoting resilience and the conservation of plant genetic resources. Earthscan, London and Sterling, pp. 109-117.

Siart, S. (2008). Strengthening local seed systems: Options for enhancing diffusion of varietal diversity of sorghum in Southern Mali. Series Communication and Extension 85. Margraf Publishers, Weikersheim.

SQCC. (2013). Seed balance sheet 2013. Available via http://sqcc.gov.np/. Accessed 27 July 2015.

SQCC. (2013). National seed vision 2013-2025. Seed Quality Control Centre (SQCC), Lalitpur.

Thomson, J.R. (1979).An introduction to seed technology. London, United Kingdom. 150p

Timsina, K., Shivakoti, G., \& Bradford, K. (2015). Supply Situation of Vegetable Seeds in Nepal: An Analysis from Policy Perspective. Nepalese Horticulture, 10(1), 26-36.

UMN. (2015). Annual Progress Report 2015. United Mission to Nepal (UMN), Rukum Cluster, Rukum and Vegetable Seed Production Cooperative Association, Musikot-1, Rukum.

Vernooy, R. (2013). In the Hands of Many: A review of community gene / Seed bank around the world. In: Community Seed Banks in Nepal: Past, Present, Future (P Shrestha, R Vernooy and P Chaudhary, eds). Proceedings of a National Workshop, LI-BIRD/USC Canada Asia/Oxfam/The Development Fund/IFAD/Bioversity International, 14-15 June 2012, Pokhara, Nepal; pp.41-46.

Vernooy, R., Sthapit, B., Otieno, G., Shrestha, P., \& Gupta, A. (2017). The roles of community seed banks in climate change adaptation. Development in Practice, 27, 316-327. 